\title{
IN VITRO ANTIBACTERIAL ACTIVITY AND GAS CHROMATOGRAPHY-MASS SPECTROMETRY ANALYSIS OF ETHANOLIC EXTRACT OF LEAVES OF ELETTARIA CARDAMOMUM L. MATON
}

\author{
PRABU P ${ }^{1}$, EDAYADULLA ${ }^{1 *}$, ANAND $S^{2}$ \\ ${ }^{1}$ Department of Chemistry, VELTECH, Avadi, Chennai - 600 062, Tamil Nadu, India. ${ }^{2}$ Department of Chemistry, Saveetha Engineering \\ College, Thandalam, Chennai-602 105, Tamil Nadu, India. Email: edayam2004@gmail.com
}

Received: 28 May 2018, Revised and Accepted: 20 August 2018

\section{ABSTRACT}

Objective: The objective of the present study is to determine the possible phytoconstituents identified by gas chromatography and mass spectrometry (GC-MS) analysis of an ethanolic leaves extract of Elettaria cardamomum L. Maton.

Methods: The extraction of E. cardamomum was done by cold solvent extraction system at room temperature. GC-MS analysis of lyophilized ethanolic leaves extract of plant samples was carried out by GC-MS-GC Clarus 500 Perkin Elmer.

Results: In E. cardamomum, 21 phytochemicals were identified among which retinal, 9-cis-showed the highest area (44.86\%) and benzeneethanamine, $\alpha$-methyl- showed the lowest area (0.12\%). The major compounds identified were retinal, 9-cis-, 1-heptatriacotanol, phytol, n-hexadecanoic acid, naphthalene,decahydro-1,1,4atrimethyl-6-methylene-5-(3-methyl-2-4-pentadienyl)-[4aS-(4a $\alpha, 5 \alpha, 8 \mathrm{a} \alpha)]-, \quad \beta$-pinene, $\quad 2 \mathrm{H}-\mathrm{pytan}-3-\mathrm{ol}, 6-$ ethenyltetrahydro-2,2,6-trimethyl-and cyclopropane, trimethanol, (2-methyl-1-propanylidene).

Conclusion: GC-MS analysis revealed the presence of hydrocarbon alkane, ester, terpenes, phenolic compounds, steroids, and fatty acids in E. cardamomum. These active phytoconstituents contribute to the medicinal efficacy of the plant, and the plant can be used for the sourcing of these compounds.

Keywords: Elettaria cardamomum, Gas chromatography-mass spectrometry, Phytoconstituents, Antibacterial.

(c) 2019 The Authors. Published by Innovare Academic Sciences Pvt Ltd. This is an open access article under the CC BY license (http://creativecommons. org/licenses/by/4. 0/) DOI: http://dx.doi.org/10.22159/ajpcr.2019.v12i1.27393

\section{INTRODUCTION}

Recently, medicinal plants are increasingly gaining importance in pharmaceutical and scientific societies, as they are the richest biological resources of traditional medicines, food supplements, and nutraceuticals [1-3]. Plants are the traditional sources for many chemicals and used as pharmaceutical biochemicals, fragrances, food colors, and flavors in different countries especially in India [4-7]. Most herbal medicines were prepared from crude plant extracts, which comprise a complex mixture of different secondary metabolites [8-10]. Gas chromatography and mass spectroscopy (GC-MS) is the methods used for testing the amount of some active principles in herbs used in cosmetics, drugs, pharmaceutical, and food industry. The chemical features of these constituents considerably differ among different species. The GC-MS analysis of the obtained plant extracts revealed the presence of various active principles in herbs which are used in cosmetics, drugs, pharmaceutical, and food industry $[11,12]$.

Elettaria cardamomum L. Maton (green cardamom) is a perennial shrub of the family Zingiberaceae. Its seeds are used as a spice, so it is called the queen of spices [13]. It stands third in the list of expensive spices throughout the world preceded by saffron and vanilla. The medicinal importance of cardamom is also mentioned in Ayurveda and Unani systems [14]. Apart from its usage in cooking, cardamom also possesses a wide range of therapeutic features such as antifungal, antibacterial, antiviral, and diuretic and carminative properties [15]. It is also applied to fight against cardiac diseases, renal problems, anorexia, asthma, and bronchitis. Furthermore, it demonstrates as an antioxidant, antiplatelet aggregation, anti-hypersensitive, and anticancerous attributes [16]. Hence, the present study was carried out to assess the phytochemical nature of medicinal plants along with their antimicrobial activities from the leaf ethanol extract of E. cardamomum by GC-MS analysis.

\section{METHODS}

Collection and identification of plant material

E. cardamomum L. Maton used for the investigation was obtained in Idukki District, near Munnar, Kerala, South India. The taxonomic identification of the plant was confirmed at the Rapinat Herbarium and Centre for Molecular Systematic, Tiruchirappalli, with the voucher number: SM001. A voucher specimen of the plant was deposited to that the Rapinat Herbarium for future reference. Fresh leaves of E. cardamomum were washed under running tap water and air dried at room temperature.

\section{Sample extraction}

The dried leaves are pulverized well in a Udy Cyclone Mill, and a $100 \mathrm{~g}$ sample of dried plant powder was extracted in $500 \mathrm{ml}$ of ethanol in a round-bottomed flask for $72 \mathrm{~h}$. The ethanolic extract was filtered using Whatman 40 filter paper, and the residue was rejected. The obtained extract was concentrated and evaporated to dryness, stored at $4^{\circ} \mathrm{C}$ in an airtight container for further use.

\section{GC-MS analysis of $E$. cardamomum}

The GC-MS analysis of E. cardamomum was carried out on a GC clarus 500 perkin elmer, Carrier gas: $1 \mathrm{ml} / \mathrm{min}$, Split: 10:1, Detector: Mass detector: Turbomass gold-perkin elmer, Software: Turbomass 5.2, sample injected: $2 \mu \mathrm{l}$, column: Elite-5MS (5\% diphenyl/95\% Dimethyl polysiloxane), $\mathrm{L} \times \mathrm{I}$.D. $30 \mathrm{~m} \times 0.25 \mathrm{~mm}$, df $0.25 \mu \mathrm{m}$, oven temperature Program: $110^{\circ} \mathrm{C}$ with $2 \mathrm{~min}$ hold, up to $200^{\circ} \mathrm{C}$ at the rate of $10^{\circ} \mathrm{C}$ per min without hold, up to $280^{\circ} \mathrm{C}$ at the rate of $5^{\circ} \mathrm{C} / \mathrm{min}$ with 9 min hold, injector temperature $250{ }^{\circ} \mathrm{C}$, total $\mathrm{GC}$ running time $36 \mathrm{~min}$, inlet line temperature $200{ }^{\circ} \mathrm{C}$, source temperature $200^{\circ} \mathrm{C}$ Electron energy: $70 \mathrm{eV}$, Mass scan (m/z): 45-450, solvent Delay: 0-2 min, and total MS running time: 45 min. The spectrum obtained in GC-MS compounds was 
Table 1: Phytocomponents identified in the alcoholic extract of leaves - E. cardamomum

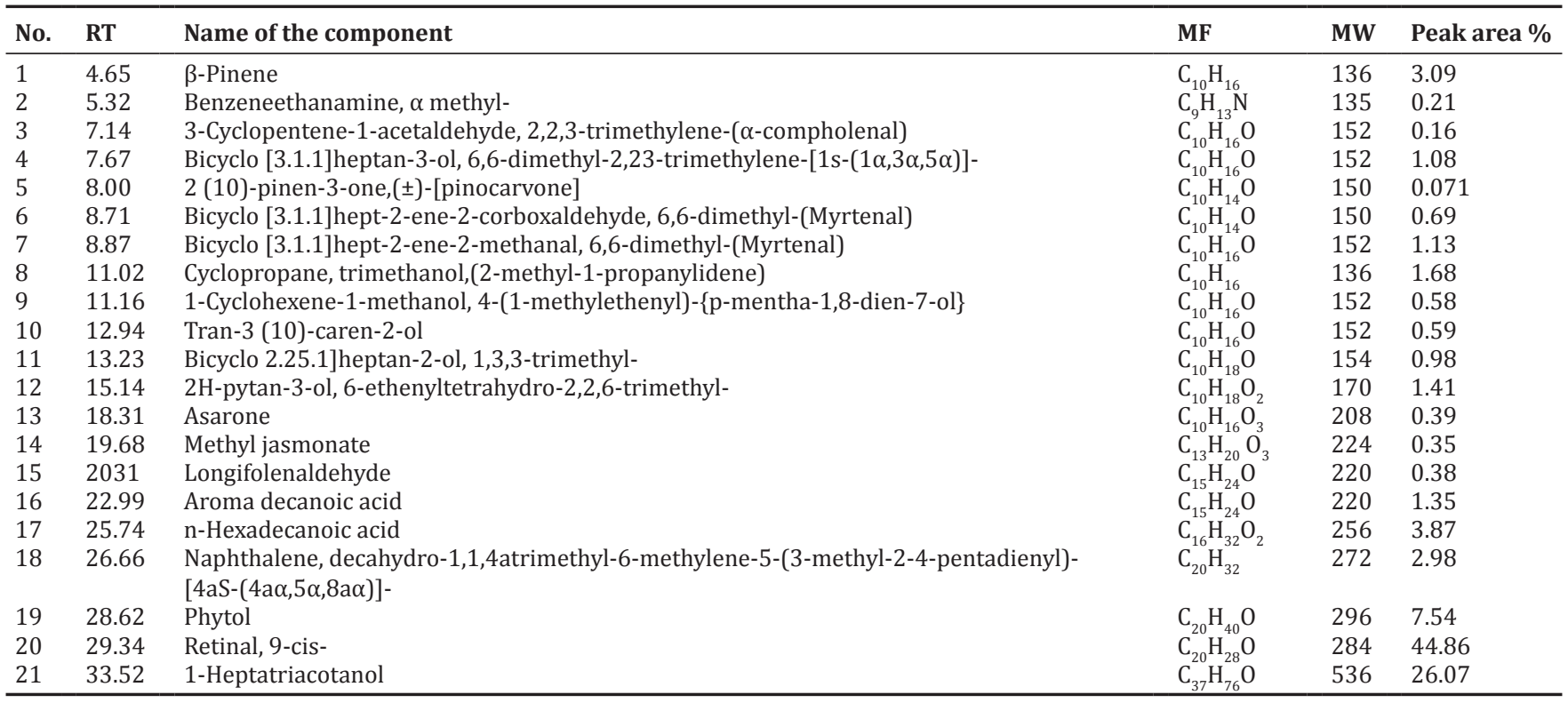

E. cardamomum: Elettaria cardamomum, MF: Molecular formula, MW: Molecular weight, RT: Retention time

Table 2: Antibacterial activity of $E$. cardamomum leaves

\begin{tabular}{|c|c|c|c|c|c|}
\hline \multirow[t]{2}{*}{ S. No } & \multirow[t]{2}{*}{ Conc. of extract $(\mu \mathrm{g} / \mathrm{ml})$} & \multicolumn{4}{|c|}{ Zone of inhibition (mm) (the mean \pm SD) } \\
\hline & & A. niger & A. flavus & E. coli & K. pneumonia \\
\hline 1 & 25 & $7 \pm 0.15$ & $8 \pm 0.75$ & $11 \pm 0.55$ & $10 \pm 0.72$ \\
\hline 2 & 50 & $13 \pm 0.40$ & $15 \pm 0.35$ & $18 \pm 0.58$ & $14 \pm 0.60$ \\
\hline 3 & 100 & $18 \pm 0.25$ & $19 \pm 0.25$ & $23 \pm 0.24$ & $16 \pm 0.22$ \\
\hline 4 & Penicillin (10) & $20 \pm 0.25$ & $24 \pm 0.30$ & $26 \pm 0.65$ & $18 \pm 0.25$ \\
\hline
\end{tabular}

Ethanolic extract of E. cardamomum observed the inhibition zone of diameter and shows antibacterial activity against microorganisms. E. cardamomum,

A. niger: Aspergillus niger, A. flavus: Aspergillus flavus, E. coli: Escherichia coli, K. pneumonia: Klebsiella pneumonia, E. cardamomum: Elettaria cardamomum

compared with the spectrum of known components using the NIST library.

\section{RESULTS AND DISCUSSION}

The GC-MS analysis of the ethanol extract of E. cardamomum clearly shows 21 peaks and indicates the presence of 21 phytochemical compounds. The identification of the phytochemical compounds was based on the retention time, molecular formula, and molecular weight. The percentage of peak area for each compound was calculated assuming total eluted compounds as percent. The details of eluted compounds were given in Table 1.

In this analysis, Retinal, 9-cis- (44.86\%) showed the highest area \%, followed by 1-Heptatriacotanol (26.07\%), Phytol (7.54\%), n-Hexadecanoic acid (3.87\%) as major phytoconstituents.

\section{Antibacterial activity}

The above-obtained plant extract was evaluated for their antibacterial activity in comparison with standard antibiotic penicillin $(10 \mu \mathrm{g} /$ $\mathrm{ml}$ ) in-vitro by disc diffusion method [17] using Aspergillus niger, Aspergillus flavus, Escherichia coli, and Klebsiella pneumonia as test organisms. Each extract was individually loaded on the $3 \mathrm{~mm}$ sterile disc at the concentration of $25 \mu \mathrm{g} / \mathrm{ml}, 50 \mu \mathrm{g} / \mathrm{ml}$ and $100 \mu \mathrm{g} /$ $\mathrm{ml}$ and subjected to antibacterial activity. The results were recorded by measuring the zone of growth inhibition surrounding the disc. The experiments were done in triplicate. The ethanolic extract of $E$. cardamomum showed a maximum zone of inhibition against $A$. niger $(18 \mathrm{~mm}$ at $100 \mu \mathrm{g} / \mathrm{ml})$ and K. pneumonia $(16 \mathrm{~mm}$ at $100 \mu \mathrm{g} / \mathrm{ml})$ when compared to that of standard (Penicillin). The antibacterial activities are mentioned in Table 2. It shows that the antibacterial activity is due to the presence of major phytochemicals like retinal, 9-cis present in leaves of the plant.

\section{CONCLUSION}

The ethanolic leaf extract of E. cardamomum has shown the presence of diverse classes of compounds possessing pharmacological and industrial importance. The extract exhibits the importance of antibacterial against bacterial strains. GC-MS analysis has been found useful in the identification of several constituents such as retinal, 1-Heptatriacotanol, Phytol, and n- hexadecanoic acid present in the ethanolic leaves extract of E. cardamomum. Further studies are needed to explore the potential of phenolic compounds from the leaves of E. cardamomum for application in drug delivery, nutritional, or pharmaceutical fields.

\section{ACKNOWLEDGMENT}

The author thanks Head of the Department, Food Safety and Quality Testing, Indian Institute of Crop Processing Technology, Thanjavur, for providing GC-MS analysis.

\section{AUTHOR'S CONTRIBUTIONS}

PP has carried out the research. NE and SA have provided study conception, the design of work, drafting of the manuscript, and critical revision.

\section{CONFLICTS OF INTEREST}

We have no conflicts of interest to declare. 


\section{REFERENCES}

1. Witkowska AM, Hickey DK, Alonso-Gomez M, Wilkinson M. Evaluation of antimicrobial activities of commercial herb and spice extracts against selected food-borne bacteria. J Food Res 2013;2:37-54.

2. Ayyanar M, Ignacimuthu S. Ethnobotanical survey of medicinal plants commonly used by Kani tribals in Tirunelveli hills of Western Ghats, India. J Ethnopharmacol 2011;134:851-64

3. Pandey N, Meena RP, Rai SM, Pandey-Rai S. Medicinal plants derived nutraceuticals: A re-emerging health aid. Int J Pharma Bio Sci 2011;2:420-41.

4. Dimple, Kumar A, Kumar V, Tomer V. Traditional medicinal systems for treatment of diabetes mellitus: A review. Int J Pharm Pharm Sci 2018;10:7-17

5. Nagja T, Vimal K, Sanjeev A. Myristica fragrans: A Comprehensive review. Int J Pharm Pharm Sci 2016;8:27-30.

6. Bikash G, Biswajit D, Sujata A, Aditya B. Preliminary phytochemical screening and in vitro anti-microbial activity of ethanolic extract of Delonix regia (Hook) Raf. Bark (Family-Leguminosae). Int J Curr Pharm Res 2018;10:43-6.

7. Pawar AT, Vyawahare NS. Phytochemical and pharmacological profile of Biophytum sensitivum (L) DC. Int J Pharm Pharm Sci 2014;6:18-22.

8. Tamizhazhagan V, Pugazhendy K. Ethnobotanical and phytopharmacological review of Pisonia alba span. Asian J Pharm Clin Res 2017;10:69-71.

9. Dilworth LL, Riley CK, Stennett DK. Plant constituents: Carbohydrates, oils, resins, balsams, and plant hormones. In: Badal S, Delgoda R, editors. Pharmacognosy: Fundamentals, Applications and Strategies. Ch. 5. Tokyo: Academic Press; 2017. p. 61-80.

10. Edayadulla N, Ramesh P. Antibacterial activity of various stem extracts of Dalbergia coromandeliana. Asian Pac J Trop Biomed 2012;2:S1388-91.

11. Gomathi D, Kalaiselvi M, Ravikumar G, Devaki K, Uma C. GC-MS analysis of bioactive compounds from the whole plant ethanolic extract of Evolvulus alsinoides (L.) L. J Food Sci Technol 2015;52:1212-7.

12. Uma B, Prabhakar K, Rajendran S, Sarayu LY. Studies on GC/MS spectroscopic analysis of some bioactive antimicrobial compounds from Cinnamomum zeylanicum. J Med Plants 2009;8:125-31.

13. Farooq A, Ali A, Khalid MA, Anwar-ul-Hassan G. Cardamom (Elettaria cardamomum Maton) oils. In: Victor RP, editor. Essential Oils in Food Preservation, Flavor and Safety. Amsterdam: Academic press; 2016. p. 295-301.

14. Shetty P, Rao SN, Rani NM. Preliminary phytochemical screening of ethanolic extract of Elettaria cardamomum fruits. Int J Univ Pharm Bio Sci 2013;2:584-90

15. Khan A, Khan QJ, Gilani AH. Pharmacological basis for the medicinal use of cardamom in asthma. Bangladesh J Pharm 2011;6:34-7.

16. Shailesh. Preliminary phytochemical and antimicrobial screening of Syzygium aromaticum, Elettaria cardamomum and Piper nigrum extracts. J Pharm Phytochem 2015;4:85-9.16.

17. Slack CB, Peutherer TT. Medical and Microbiology, a Guide to Microbial Infections, Pathogenesis, Immunity, Laboratory Diagnosis and Control. London: Churchill Livingston; 2002. p. 225-85. 